ks. Roman Karwacki

UKSW Warszawa

DOI: $10.15290 /$ std.2015.01.08

\title{
ET CREAVIT DEUS HOMINEM PODSTAWY ANTROPOLOGII TEOLOGICZNEJ
}

\section{ET CREAVIT DEUS HOMINEM FUNDAMENTALS OF THEOLOGICAL ANTHROPOLOGY}

Religious and theological question about the man may come from Divine Revelation. It is impossible to truly answer the question without reffering to the Creator since He is "creavit Deus" the truth of revelation through the faith of the wise man to the fullness of life. God, who is love and life, created man in His own image and likeness, created man and woman. In the humanity of man and woman God inscribed a particular calling to participate in the mystery of communio of God and entrusted the task of dominion over the earth, over creation. God gives grace to his goodness on the way of salvation. He is the Creator and Savior.

Key words: God, Creator, Holy Trinity, Creation, Man and Woman, sin, Jesus Christ, Love, Forgiveness, Mercy, Redemption, Salvation, Anthropology, Eschatology.

Człowiek. Kim jest człowiek? Jakie jest jego pochodzenie? Jaki jest jego cel? Jaki jest sens jego życia? Odpowiedzi prawdziwej na takie pytania nie można udzielić bez odniesienia do Stwórcy, ponieważ to creavit Deus ( $\mathrm{Rdz} 1,17)$ „niebo i ziemię" ${ }^{1}$, „rzeczy widzialne i niewidzialne”, anioła i człowieka, dla chwały i do chwały, mimo upadku, bo jest „łaska Pana Jezusa ze wszystkimi” (Ap 22, 21). Prawda Objawienia przez wiarę rozumnego człowieka ku pełni życia. Albowiem

\footnotetext{
1 „Coeli et terrae creatorem”, DS 19; „universorum creatorem”, DS 21.22; „creatorem coeli et terrae", DS 27.28.30.36; BFn IX,4.

2 „Creatorem omnium visibilium et invisibilium”, DS 50.125.150; BFn IX,7.10.
} 
On (Ojciec) uwolnił nas spod władzy ciemności i przeniósł do królestwa swego umiłowanego Syna, w którym mamy odkupienie - odpuszczenie grzechów. On jest obrazem Boga niewidzialnego - Pierworodnym wobec każdego stworzenia, bo w Nim zostało wszystko stworzone: i to, co w niebiosach, i to, co na ziemi, byty widzialne i niewidzialne, czy Trony, czy Panowania, czy Zwierzchności, czy Władze. Wszystko przez Niego i dla Niego zostało stworzone. On jest przed wszystkim i wszystko w Nim ma istnienie. I On jest Głową Ciała - Kościoła. On jest Początkiem, Pierworodnym spośród umarłych, aby sam zyskał pierwszeństwo we wszystkim. Zechciał bowiem (Bóg), aby w Nim zamieszkała cała Pełnia, i aby przez Niego znów pojednać wszystko z sobą: przez Niego - i to, co na ziemi, i to, co w niebiosach, wprowadziwszy pokój przez krew Jego krzyża” (Kol 1, 13-20).

\section{Creavit Deus}

„In principio creavit Deus ( $\mathrm{Rdz} 1,17)$ - Bóg jest Stwórcą wszystkiego. Chrześcijańskie wyznania wiary (Symbole wiary): Skład Apostolski i Credo mszalne mówią najpierw o Stworzycielu, bo od Niego pochodzi wszelkie stworzenie i tylko w Nim ma swoje spełnienie ${ }^{3}$. Nie jest możliwe zrozumienie dzieła stworzenia bez Stworzyciela.

Stworzenie jako dzieło jedyne w swoim rodzaju, tak ściśle jest związane ze swą osobową podstawą w Bogu, że tego związu nigdy nie może stracić oraz że znaczenie i wyjaśnienie wszelkiego stworzenia bez tego odniesienia do Stworzyciela jest niemożliwe. Stworzycielem jest Trójosobowy Bóg. Dlatego Trójca Święta musi być uznana i przedstawiona jako Boska zasada (principium) Stworzenia 4 .

Trójca Święta jest jedyną, wspólną zasadą Stworzenia - unum universorum principium ${ }^{5}$. Tylko Trójca Święta ,jest początkiem wszystkich rzeczy universorum principium", poza którą nie można znaleźć innego ${ }^{6}$. Potwierdził to Sobór Florencki: „(Kościół) mocno wierzy, wyznaje i głosi jednego, prawdziwego Boga, Ojca i Syna i Ducha Świętego, Stworzyciela wszystkich rzeczy widzialnych i niewidzialnych"?

Dzieło Stworzenia jest związane z Trójosobowym Bogiem. Święty Augustyn ujmuje to w formule: „Od Ojca przez Syna w Duchu Świętym pochodzi

$3 \quad$ Zob. DS 19; 21-22; 27-30; 125; 150; 800; 1333.

$4 \quad$ Zob. L. Scheffczyk, Schöpfung als Heilseröffnung. Schöpfungslehre, Aachen 1997, s. 114n.

5 Conc. Lateranense IV, De fide catholica (1215 r.), DS 800, BFn IV 33.

6 Ibidem, DS 804, BFn IV, 35.

7 „Firmissime credit, profitetur et praedicat, unum verum Deum, Patrem et Filium et Spiritum Sanctum, esse omnium visibilium et unvisibilium creatorem”. Conc. Florentinum, Decretum pro Jacobitis (1442 r.), DS 1333. 
świat”. Tę formułę rozwija św. Tomasz z Akwinu: „Ojciec stworzył świat przez swoje Słowo, którym jest Syn, i przez Swoją Miłość, którą jest Duch Święty” i dodaje: „Dlatego pochodzenia Osób są podstawą stworzenia świata”. Osoby Trójcy Świętej, w jedności swej natury (ordo naturae), odnoszą się wzajemnie do siebie. Wspólne działanie Osób Trójcy Świętej urzeczywistnia się w porządku natury (ordo naturae): Ojciec nie otrzymuje jej od nikogo ${ }^{10}$, Syn otrzymuje ją od Ojca, a Duch Święty od nich Obu ${ }^{11}$ oraz w porządku osób (ordo personarum): pierwszeństwo stwórczej Wszechmocy Ojca, a także (proprium) Syna i Ducha Świętego ${ }^{12}$. Osoby Trójcy Świętej działają wspólnie ad extra. Ta troista apropriacja w jedności potentia generandi et potentia creandi ukazuje sens wzorczego odniesienia między pochodzeniem Osób a pochodzeniem stworzenia: procesiso personarum divinarum est causa processionis creaturarum ${ }^{13}$. Zasada trynitarna wyklucza wszelką konieczność, potwierdza zaś w sposób absolutny wolność stwórczego aktu Bożego oraz prowadzi do uznania w sposób bezwzględny pełnej dobroci i pozytywności stworzenia ${ }^{14}$.

Stworzenie jest wyłącznie dziełem Boga. Wszystko co istnieje, pochodzi od Boga w sposób wolny i dobrowolny. Przed tym dziełem Boga nic nie istnieje. Bóg stworzył z niczego (ex nihilo). To nic nie stanowi tworzywa ani dwubiegunowości: Byt i Nicość. Bóg jest Stwórcą, a nie twórcą. Stworzenie istnieje, ponieważ Bóg przekazuje mu istnienie i nic tego nie poprzedza.

Papież Leon I podkreśla w liście do hiszpańskiego biskupa Turribiusza z Astorgii, że „poza tą zaś najwyższą Trójcą, jednym wspólistotnym, wiecznym i niezmiennym Bóstwem nie ma nic wśród stworzeń, co w swoim początku nie zostałoby stworzone $z$ niczego" 15 . Formuła ta otrzymała ostateczne potwierdzenie na Soborze Laterańskim IV w definicji przeciw Albigensom i Katarom:

$8 \quad$ św. Augustyn, Tract. In Joh. 20.9.

9 „Unde et Deus Pater operatus est creaturam per suum verbum, quod est Filius et per suum amorem, qui est Spiritus Sanctus. Et secundum hoc processiones personarum sunt rationes productionis creaturorum", św. Tomasz z Akwinu, S. th. I, q. 45 a 6.

10 „Pater principium totius divinitatis”, św. Tomasz z Akwinu, Scriptum de Sententiis. Liber primus, d. 29. Exp. Text. „Principium sine principio”. Ibidem, q. 39, a.8.

11 Ibidem, ad 4: św. Tomasz z Akwinu, Questiones disputate de Potentia Dei, q. 10, a. 2, co.

12 św. Tomasz z Akwinu, Scriptum de Sequentiis. Liber primus, q. 38, a. 8.

13 Ibidem, d. 10, q. 1, a. 1.

14 Zob. A. Scola, Osoba ludzka. Antropologia teologiczna, Poznań 2005, s. 80.

15 „Praeter hanc autem summe Trinitatis unam consubstantialem et sempiternam atque incommunitabilem deitatem nihil omnino creaturarum est, quod non in ex ordio sui ex nihilo creatum sit”. Leon I, Ep. „Quam landebiliter” ad Turib. Ep. Astur (21.07.447), DS 285. 
Całą mocą wierzymy i bez zastrzeżenia wyznajemy, że jeden tylko jest prawdziwy Bóg, odwieczny i nieskończony, niezmienny, niepojęty, wszechmocny, niewysłowiony, Ojciec, Syn i Duch Święty: trzy Osoby, ale jedna istota, substancja, czyli natura zupełnie niezłożona. Ojciec od nikogo nie pochodzi, Syn od samego tylko Ojca, Duch Święty jednocześnie od Obydwóch, bez początku, zawsze i bez końca. Ojciec Rodziciel, Syn zrodzony, Duch Święty pochodzący: wspólistotni i równi sobie, współwszechmocni i współwiekuiści; są jednym wszystkich rzeczy początkiem, stwórcą wszystkiego, co widzialne i niewidzialne, co duchowe i materialne. On to wszechmocną swoją potęgą, od początku czasu, utworzył jednakowo z nicości i jeden, i drugi rodzaj stworzeń, tj. istoty duchowe i materialne: aniołów i świat, a na koniec naturę ludzką, jakby łączącą te dwa światy, złożoną z duszy i ciała. Diabeł bowiem i inne złe duchy zostały przez Boga stworzone jako dobre z natury, ale sami uczynili się złymi. Człowiek zaś zgrzeszył za podszeptem diabła. Ta Święta Trójca, według wspólnej istoty indywidualna, a według właściwości osobowych zróżnicowana, najpierw przez Mojżesza i innych Proroków oraz przez innych wysłanników swoich, dała rodzajowi ludzkiemu zbawienną naukę zgodnie z mądrze zaplanowanym rozkładem czasów ${ }^{16}$.

\section{Potwierdził Sobór Watykański I:}

Ten jedyny i prawdziwy Bóg z dobroci swojej i wszechmocną potęgą swoją, nie dla zwiększenia lub zdobycia większego szczęścia, ale dla objawienia swojej doskonałości przez dobra, jakich stworzeniom udziela, zupełnie wolną decyzją „od początku czasu, utworzył jednakowo z nicości i jeden, i drugi rodzaj stworzeń, tj. istoty duchowe i materialne: aniołów i świat, a na koniec naturę ludzką, jakby łączącą te dwa światy, złożoną z duszy i ciała"17.

Albowiem „[Ten jeden Bóg] wszechmocną swą potęgą równocześnie, od początku czasu, stworzył z nicości (ex nihilo)"18. Bóg różni się od stworzenia. Stworzenie jest Jego i tylko Jego dziełem ${ }^{19}$.

Motyw i cel stworzenia stanowi Bóg sam, Jego chwała i Jego miłość: „Albowiem z Niego i przez Niego i dla Niego wszystko. Jemu chwała na wieki. Amen” (Rz 11, 36). „Jest jasne, że Bóg nie był zmuszony żadną zewnętrzną koniecznością stworzyć świat, lecz tylko ze swej dobroci, tj. z miłości do siebie" ${ }^{20}$ - jak mówi św. Augustyn. Drugorzędnym celem jest udział stworzeń w Jego dobru i jego zbawieniu, uszczęśliwieniu ${ }^{21}$.

Spojenie celu świata ma swoją podstawę w Chrystusie, który jako prawzór Stworzenia i jako cel Stworzenia, Bóg Człowiek, sam poniekąd stanowi w sobie

16 Sobór Laterański IV (1215), DS 800, BFn IV,30; V,10.

17 Sobór Watykański I (1870), DS 3002; BFn V,19.

18 Sobór Laterański IV, DS 800, BFn IV,33; Zob. Sobór Watykański I, DS 3002, BFn V,19.

19 Zob. L. Scheffczyk, Schöpfung..., s. 133-154; . A. Scola, Osoba ludzka..., s. 104-115.

20 św. Augustyn, De civitate Dei, XI,24.

21 Zob. L. Scheffczyk, Schöpfung..., s. 150. 
Summa creatura, tzn. w sobie jednoczy całe stworzenie w najwyższej doskonałości i jak wyraża Apokalipsa, jest Alfą i Omegą Stworzenia (por. Ap 1, 8; 22, 13). Chrystus jako Alfa i Omega niejako zwiera w sobie i w sobie jednoczy rzeczywistość. Cel świata i człowieka w Chrystusie wypełni się w eschatologicznym przemienieniu stworzenia w nowym niebie i nowej ziemi (por. Ap 21, 1) ${ }^{22}$.

Stworzenie jest początkiem historii Zbawienia. Stworzenie miało początek w czasie, „od początku czasu”23. Stwórcze działanie Boga trwa w czasie. Albowiem Stworzenie jest ciągłym aktem Boga, który utrzymuje w istnieniu wszystko, co stwarza. To conservatio et gubernatio divina ${ }^{24}$ ułatwia teologiczne rozumienie Opatrzności Bożej, jak wyraża Apostoł Paweł: „Wiemy też, że Bóg z tymi, którzy Go miłują, współdziała we wszystkim dla ich dobra, z tymi, którzy są powołani według [Jego] zamiaru" (Rz 8, 28). Stwórcze działanie Trójjedynego Boga osiągnie swój kres „gdy już wszystko zostanie Mu (Chrystusowi) poddane, wtedy i sam Syn zostanie poddany Temu, który Synowi poddał wszystko, aby Bóg był wszystkim we wszystkich" (1 Kor 15, 28).

\section{Creatio}

Kościół wyznaje wiarę w jednego Boga „Stworzyciela nieba i ziemi” (Skład Apostolski) ${ }^{25}$ : „Stworzyciela nieba i ziemi, wszystkich rzeczy widzialnych i niewidzialnych" (Credo mszalne) ${ }^{26}$. Sobór Laterański IV (1215) definiuje:

Stwórca wszystkiego, co widzialne i niewidzialne, co duchowe i materialne. [Ten jeden Bóg] wszechmocną swoją potęgą równocześnie, od początku czasu, utworzył z nicości jeden i drugi rodzaj stworzeń: istoty duchowe i materialne, to znaczy aniołów i świat, a na koniec [naturę] ludzką, jakby łączącą te dwa światy, złożoną $z$ duszy i ciała. Diabeł bowiem i inne złe duchy zostały od Boga stworzone jako dobre z natury, ale same stały się złymi. Człowiek zaś zgrzeszył za podszeptem diabła ${ }^{27}$.

22 Zob. ibidem, s. 160-163.

23 Sobór Laterański IV, DS 800, BFn V,10; Sobór Watykański I, DS 3002, BFn V,19. św. Tomasz z Akwinu, Scriptum de Sequentiis. Liber primus, q. 8, a. 1. „Creatorem caeli et terrae”. Ordo Romanus baptismalis (XI w.), DS 30, BFn IX,4.

26 „Omnium visibilium et invisibilium factorem”. Symbolum Nicaenum I (19.01.325), DS 125; BFn IX,7.

27 „Creator omnium visibilium et invisibilium, spiritualium et corporalium: qui sua omnipotenti virtute simul ab initio temporis utramque de nihilo condidit creaturam, spiritualem et corporalem, angelicam videlicet et mundanam: ac deinde humanam, quasi communem ex spiritu et corpore constitutam. Diabolus enim et alii daemones a Deo quidem natura creati sunt boni, sed ipsi per se facti sunt mali. Homo vero diaboli suggestione peccavit". Concilium Lateranense IV (1215), De fide catholica, DS 800; BFn IX,29. 
Bóg stworzył aniołów jako istoty duchowe, osobowe. Aniołowie są w służbie stworzeniu i historii zbawienia. Taką „egzystencję aniołów potwierdzają prawie wszystkie księgi Pisma Świętego" ${ }^{28}$. Aniołowie różnią się od materialnego Kosmosu. Ich egzystencję określa służba Bogu Zbawcy i pomoc ludziom w osiągnięciu Zbawienia.

Liczni jednak aniołowie odeszli od Boga Stwórcy: „Diabeł bowiem i inne złe duchy zostały przez Boga stworzone jako dobre z natury, ale sami uczynili się złymi. Człowiek zaś zgrzeszył za podszeptem diabła"29.

Bóg stworzył wszystko: „Na początku Bóg stworzył niebo i ziemię” ( $\mathrm{Rdz} 1,1)$. Bóg dokonuje poszczególnych dzieł stwórczych. Bóg stworzył wszystko i całość rzeczywistości w określonym porządku, a „wszystko co uczynił, było bardzo dobre" ( $\operatorname{Rdz} 1,31)$. Stworzenie pochodzi od Boga i istnieje dla Jego chwały. „Niebo i ziemia”, „rzeczy widzialne i niewidzialne”, to rzeczywistość duchowa i materialna, całość stworzenia będąca obszarem bytowania człowieka.

\section{Pochodzenie człowieka bezpośrednio od Boga}

Pismo Święte uczy bowiem, że człowiek został stworzony „na obraz Boży”, zdolny do poznania i miłowania swego Stwórcy, ustanowiony przez Niego panem wszystkich stworzeń ziemskich, aby rządził i posługiwał się nimi, dając chwałę Bogu. „Czym jest człowiek, że o nim pamiętasz, i czym - syn człowieczy, że się nim zajmujesz? uczyniłeś go niewiele mniejszym od istot niebieskich, chwałą i czcią go uwieńczyłeś. Obdarzyłeś go władzą nad dziełami rąk Twoich; złożyłeś wszystko pod jego stopy" (Ps 8, 5-7). Lecz Bóg nie stworzył człowieka samotnym: gdyż od początku „mężczyznę i niewiastę stworzył ich” (Rdz 1, 27); a zespolenie ich stanowi pierwszą formę wspólnoty osób ${ }^{30}$

- podkreśla Sobór Watykański II.

„Na obraz Boży”. Stworzenie człowieka ,jest włączone w rytm siedmiu dni stworzenia świata” ${ }^{11}$, który był dobry: „I widział Bóg, że były dobre. A wreszcie rzekł Bóg: Uczyńmy człowieka na Nasz obraz, podobnego Nam. Niech panuje nad rybami morskimi, nad ptactwem powietrznym, nad bydłem, nad ziemią i nad wszystkimi zwierzętami pełzającymi po ziemi!” (Rdz 1, 25-26). Tak więc człowiek stworzony w świecie i wraz ze światem widzialnym, by czynić ziemię poddaną, a zarazem ponad światem. Ukazuje to wyjątkowość człowieka w stosunku do całego stworzenia. Jednak człowiek nie jest podobny do świata, lecz

28 św. Grzegorz Wielki, Hom 34 in evang 8.

29 Sobór Laterański IV, De fide catholica (1215 r), DS 800, BFn V,10.

$30 \quad$ KDK 12.

31 Jan Paweł II, Mężczyzną i niewiasta stworzyt ich, Libreria Editrice Vaticana 1986, s. 12. 
tylko do Boga: „Stworzył więc Bóg człowieka na swój obraz, na obraz Boży go stworzył: stworzył mężczyznę i niewiastę" ( $\operatorname{Rdz} 1,27)$. Na obraz Boga, który „jest miłością” (1 J 4, 8.16). Tak więc

Człowiek w świetle pierwszych zdań Biblii nie może być rozumiany i wytłumaczony do końca przy pomocy kategorii, których dostarcza „świat”: widzialny świat ciał. I to pomimo że sam człowiek również jest ciałem. Rdz 1, 27 stwierdza, iż ta zasadnicza prawda o człowieku odnosi się zarówno do mężczyzny jak i do kobiety: „na obraz Boga go stworzył - stworzył mężczyznę i niewiastę" ${ }^{\prime \prime 2}$,

oboje wszakże zostali stworzeni na obraz i podobieństwo Boga osobowego ${ }^{33}$.

Człowiek pochodzi bezpośrednio od Boga: „wtedy to Pan Bóg ulepił człowieka z prochu ziemi i tchnął w jego nozdrza tchnienie życia, wskutek czego stał się człowiek istotą żywą" (Rdz 2, 7). Człowiek z ziemi - adamah, Adam (Rdz 2, 7), przy czym uformowany przez Boga. „Proch” znaczy kruchość, słabość, znikomość (marność), nietrwałość (krótkotrwałość, doczesność). Tchnienie, „Tchnienie życia” (nefes) znaczy żywotność człowieka. Człowiek i jego życie całkowicie zależą od Boga Stwórcy, który stworzył człowieka ${ }^{34}$.

Człowiek stworzony na „obraz Boży” to szczyt stwórczej inicjatywy Boga, wskazuje na wyjątkowość człowieka w stosunku do całości stworzenia, że jest usytuowany $\mathrm{w}$ kondycji panowania nad innymi istotami żyjącymi, na jego odniesienie do kobiety, adresata Bożego błogosławieństwa (por. $\mathrm{Rdz} 1,28$ ), na stwórczy dar rodzenia, na jego obraz (por. $\operatorname{Rdz} 5,3$ ), na zakaz zabijania człowieka $(\operatorname{Rdz} 9,6)$. „Podobieństwo” będące synonimem „obrazu”, wskazuje, że człowiek wprawdzie jest blisko Boga, lecz nie jest równy Bogu. Człowiek jest „obrazem Boga Stwórcy” (imago Dei), nie zaś, jak mówi cybernetyka, „obrazem maszyny" (imago machinae), skonstruowaną istotą, którą ciągle można coraz bardziej doskonalić35.

Doskonałość „obrazu Boga” wyraża się we Wcielonym Synu Bożym, Bogu-Człowieku, ostatnim Adamie (1 Kor 15, 45-47), Jezusie Chrystusie, który jest „obrazem Boga niewidzialnego” (Kol 1, 15; 2 Kor 4, 4), „odblaskiem Jego chwały i odbiciem Jego istoty" (Hbr 1, 3). Jezus Chrystus

jest obrazem Boga niewidzialnego - Pierworodnym wobec każdego stworzenia, bo w Nim zostało wszystko stworzone: i to, co w niebiosach, i to, co na ziemi, byty widzialne i niewidzialne, czy Trony, czy Panowania, czy Zwierzchności, czy

$32 \quad$ Ibidem, s. 13.

33 Jan Paweł II, List apostolski Mulieris dignitatem, n. 6.

34 Zob. Dekret Komisji Biblijnej (1909); L. Scheffczyk, Schöpfung..., s. 212n. DS 3514, BFn V,27. Dekret Komisji Biblijnej (1909).

35 Zob. L. Scheffczyk, Schöpfung..., s. 20. 
Władze. Wszystko przez Niego i dla Niego zostało stworzone. On jest przed wszystkim i wszystko w Nim ma istnienie. I On jest Głową Ciała - Kościoła. On jest Początkiem, Pierworodnym spośród umarłych, aby sam zyskał pierwszeństwo we wszystkim. Zechciał bowiem (Bóg), aby w Nim zamieszkała cała Pełnia, i aby przez Niego znów pojednać wszystko z sobą: przez Niego - i to, co na ziemi, i to, co w niebiosach, wprowadziwszy pokój przez krew Jego krzyża (Kol 1, 15-20).

Człowiek jest obrazem lub odbiciem Chrystusa przez chrzest: „My wszyscy $z$ odsłoniętą twarzą wpatrujemy się w jasność Pańską jakby w zwierciadle; za sprawą Ducha Pańskiego, coraz bardziej jaśniejąc, upodabniamy się do Jego obrazu" (2 Kor 4, 18). Ochrzczony w całym swoim bycie jest włączony w rzeczywistość życia Chrystusa w odniesieniu osoby do Osoby, udział w wydarzeniu zbawczym, którego celem i spełnieniem jest chwała u Ojca. W tym chrześcijańska antropologia osiąga wzniosły, mistyczny poziom (szczyt): od początku stworzenia aż po eschatologiczne wypełnienie ${ }^{36}$.

„Mężczyzną i kobietą”. „Stworzył więc Bóg człowieka na swój obraz, na obraz Boży go stworzył: stworzył mężczyznę i niewiastę" (Rdz 1, 27). Płciowość pochodzi z Bożego Stworzenia. To

Pan Bóg rzekł: „Nie jest dobrze, żeby mężczyzna był sam; uczynię mu zatem odpowiednią dla niego pomoc". Ulepiwszy z gleby wszelkie zwierzęta lądowe i wszelkie ptaki powietrzne, Pan Bóg przyprowadził je do mężczyzny, aby przekonać się, jaką on da im nazwę. Każde jednak zwierzę, które określił mężczyzna, otrzymało nazwę istota żywa. I tak mężczyzna dał nazwy wszelkiemu bydłu, ptakom powietrznym i wszelkiemu zwierzęciu polnemu, ale nie znalazła się pomoc odpowiednia dla mężczyzny. Wtedy to Pan sprawił, że mężczyzna pogrążył się w głębokim śnie, i gdy spał, wyjął jedno z jego żeber, a miejsce to zapełnił ciałem. Po czym Pan Bóg z żebra, które wyjął z mężczyzny, zbudował niewiastę. A gdy ją przyprowadził do mężczyzny, mężczyzna powiedział: Ta dopiero jest kością z moich kości i ciałem z mego ciała! Ta będzie się zwała niewiastą, bo ta z mężczyzny została wzięta (Rdz 2, 18-23).

Bóg sam stwarza kobietę bez udziału mężczyzny, lecz w tożsamości człowieczeństwa: kobieta z mężczyzny - jedność natury, niesklonowana - różność osób, ku pomocy - we wspólnocie, ku stwórczemu życiu - w jedności osób (communio personarum), dla osobowej płodności - nowej osoby. Istota ludzka bytuje zawsze i jedynie jako kobieta lub jako mężczyzna ${ }^{37}$.

Człowiek istnieje zawsze i tylko jako mężczyzna lub jako kobieta. Płciowość dla człowieka jest konstytutywna. Mężczyzna i kobieta są równi, lecz nieprzezwyciężalnie odmienni. Nawet w konstytucji somatycznej ciało mężczyzny aż

\footnotetext{
$36 \quad$ Zob. ibidem, s. 233n.

37 Zob. Jan Paweł II, Adhortacja Apostolska Familiaris consortio, 1.
} 
do ostatniej komórki jest męskie, a ciało kobiety jest kobiece ${ }^{38}$. Ta „dwoistość natomiast oznacza wszystko to, czym na gruncie tożsamości człowieczeństwa okazuje się męskość i kobiecość stworzonego człowieka"39.

„Im błogosławił”. Człowiekowi, którego Bóg „stworzył jako mężczyznę i kobietę” ( $\mathrm{Rdz} 1,27)$ dany został udział w stwórczej mocy Boga: „Bóg im błogosławił, mówiąc do nich: Bądźcie płodni i rozmnażajcie się, abyście zaludnili ziemię i uczynili ją sobie poddaną" ( $\mathrm{Rd} z 1,28)$. W spełnianiu tego zadania, „jakim jest przekazywanie i wychowanie, obowiązku, który trzeba uważać za główną ich misję, są współpracownikami Boga-Stwórcy i jakby jej wyrazicielami”40.

Z błogosławieństwem płodności złączona jest świętość. Płodność jest darem Boga Świętego:

Pierwsza zaś niewiasta - Ewa - w chwili, kiedy po raz pierwszy objawiła się macierzyńska dojrzałość jej ciała, kiedy „poczęła i porodziła”, mówi: „Urodziłam człowieka (mężczyznę) z pomocą Jahwe" (Rdz 4,1). Słowa te wyrażają całą teologiczną głębię rodzicielstwa - prokreacji. Ciało kobiety staje się miejscem poczęcia nowego człowieka. W jej łonie ten poczęty człowiek przybiera swój ludzki kształt, zanim zostanie wydany na świat. Jednorodność somatyczna mężczyzny i kobiety, która znalazła swój pierwszy wyraz w jego słowach „jest kością z moich kości i ciałem z mego ciała!" (Rdz 2, 23), potwierdza się z kolei w słowach pierwszej kobiety-matki: „urodziłam człowieka”. Pierwsza rodząca kobieta ma pełną świadomość tajemnicy stworzenia odnawiającej się w ludzkim rodzeniu. Ma też ona pełną świadomość stwórczego udziału Boga w swoim - i swego męża - ludzkim rodzicielstwie, skoro mówi: „urodziłam z pomocą Jahwe”. Nie może tu być mowy o żadnym pomieszaniu zakresów działających przyczyn. Pierwsi rodzice przekazują wszystkim ludzkim rodzicom - również po grzechu, wraz z owocem drzewa poznania dobra i zła, niejako u progu wszystkich „historycznych” doświadczeń - podstawową prawdę o rodzeniu się człowieka: obrazu Boga wedle praw ciała. W tym to, zrodzonym z kobiety-rodzicielki za sprawą mężczyzny-rodzica nowym człowieku odtwarza się ten sam za każdym razem „obraz Boga”, który ukonstytuował samo człowieczeństwo pierwszego człowieka: „jest kością z moich kości i ciałem z mego ciała!” (Rdz 1, 27) (1. $^{41}$

W tajemnicy stworzenia człowiek „został obdarowany jednością tego, co w nim po ludzku, a zarazem poprzez ciało - męskie i tego, co w nim po ludz$\mathrm{ku}$, a zarazem poprzez ciało - kobiece. Nad tym zaś od początku spoczęło też błogosławieństwo płodności związanej z istotowo ludzkim rodzeniem (por. $\operatorname{Rdz} 1,28) " 42$.

$38 \quad$ Zob. A. Scola, Osoba ludzka, dz. cyt., s. 185.

39 Jan Paweł II, Mężczyzna i niewiasta stworzyt ich..., s. 37.

$40 \quad$ KDK 50.

41 Ibidem, s. 86-88.

42 Ibidem, s. 40. 
„Jednym ciałem”. „Dlatego to mężczyzna opuszcza ojca swego i matkę swoją i łączy się ze swą żoną tak ściśle, że stają się jednym ciałem" (Rdz 2, 24). To

sformułowanie biblijne, nadzwyczaj zwięzłe i proste, wskazuje na płeć, na kobiecość i męskość, jako na tę właściwość człowieka - mężczyzny i kobiety - która pozwala im „stając się jednym ciałem”, poddać zarazem całe swoje człowieczeństwo błogosławieństwu płodności ${ }^{43}$.

W naturze ludzkiej zakorzenione jest Boże błogosławieństwo płodności. Dlatego to mężczyzna opuszcza ojca i matkę, by złączyć się ze swoją żoną stając się jednym ciałem. I nie jest to jakieś stopienie się, lecz zjednoczenie w miłości wyłącznej i definitywnej ku prokreacji - z pomocą Pana. Albowiem

w każdym zjednoczeniu małżeńskim mężczyzny i kobiety zostaje na nowo odkryte to samo pierwotnie jednoczące poczucie sensu ciała w jego męskości i kobiecości, wskazuje zarazem, że w każdym takim zjednoczeniu odtwarza się niejako tajemnica stworzenia w całej swojej pierwotnej głębi i życiodajnej mocy. „Wzięta z mężczyzny” niewiasta jako „ciało z jego ciała”, zostaje z kolei jako „żona” wzięta z mężczyzny poprzez macierzyństwo: jako „matka żyących” (Rdz 3, 20) - jej macierzyństwo bowiem również w nim ma swój początek. Rodzenie zakorzenione jest w stworzeniu i za każdym razem poniekąd odtwarza jego tajemnicę ${ }^{44}$.

I tak oto „obrazowi monoteistycznego Boga odpowiada małżeństwo monogamiczne. Małżeństwo oparte na miłości wyłącznej i definitywnej staje się obrazem relacji Boga z jego ludem, i odwrotnie: sposób, w jaki miłuje Bóg, staje się miarą ludzkiej miłości”"

Owocem jedności jest nowy człowiek stworzony na obraz Boży. Płciowość, miłość i prokreacja są istotnie złączone ze sobą. Obiektywnie jest niemożliwe usunięcie któregokolwiek z nich bez substancjalnej zmiany istoty każdego z nich. Naruszenie któregokolwiek z nich: płciowości, miłości, prokreacji nie pozwala stać się „jednym ciałem” w błogosławieństwie płodności, a wiedzie ostatecznie do sprowadzenia prokreacji do reprodukcji, czy produkcji, a miłości do fantazmu dwupłciowości, czy egoizmu ${ }^{46}$.

„Chociaż mężczyzna i jego żona byli nadzy, nie odczuwali wobec siebie wstydu”. Stworzeni przez Boga z Jego błogosławieństwem i uświęceniem, przed Jego obliczem mężczyzna oraz kobieta, nadzy, nie odczuwają wstydu wobec siebie, ani lęku przed Bogiem.

\footnotetext{
$43 \quad$ Ibidem, s. 42n.

44 Ibidem, s. 42-45.

45 Benedykt XVI, Encyklika Deus caritas est, n. 11.

46 Zob. A. Scola, Osoba ludzka..., s. 190.
} 
Widząc siebie wzajemnie jakby wzrokiem samej tajemnicy stworzenia, mężczyzna i kobieta widzą siebie tym pełniej i wyraziściej samym zmysłem wzroku: oczyma ciała. Widzą bowiem i ogarniają siebie z całym pokojem wewnętrznego wejrzenia, który właśnie stwarza pełnię osobowej intymności. Jeśli „wstyd” niesie z sobą swoiste ograniczenie widzenia zmysłem wzroku, oczyma ciała, to dzieje się to przede wszystkim na gruncie zachwianej i jakby „zagrożonej” osobowej intymności tego widzenia. Wedle Rdz 2, 25 mężczyzna i kobieta „nie doznają wzajemnie wstydu”: widząc i ogarniając siebie z całym pokojem wewnętrznego wejrzenia, „komunikują" w pełni człowieczeństwa, które objawia się w nich jako wzajemnie dopełnione właśnie dlatego, że jest „męskie” i „kobiece”. A zarazem „komunikują” na gruncie tej komunii osób, w której poprzez swą kobiecość i męskość stają się wzajemnym darem dla siebie. W ten sposób osiągają we wzajemności szczególne poczucie sensu swego ciała. Pierwotne znaczenie nagości odpowiada takiej prostocie i pełni widzenia, w której poczucie sensu ciała rodzi się jakby w samym sercu ich wspólnoty-komunii. Nazwiemy je „oblubieńczym”. Mężczyzna i kobieta w Rdz 2, 23-25 wyłaniają się u samego „początku” z takim właśnie poczuciem sensu swego ciała ${ }^{47}$.

„Wtedy Bóg pobłogosławił ów siódmy dzień i uczynił go świętym”. Bóg swym błogosławieństwem wpisał w dzieło stworzenia święty porządek. Tak więc każda bez wyjątku rzeczywistość powinna być przyporządkowana Bogu. Do Niego należą czas i przestrzeń. On jest Bogiem nie jednego tylko dnia, ale wszystkich dni człowieka ${ }^{48}$. Do Niego należy i Jego jest każdy człowiek, od pierwszego Adama do ostatniego na końcu czasów. Siódmy dzień zamyka dzieło stworzenia, a dzień ósmy rozpoczyna nowe stworzenie, dzieło Odkupienia. Kult jest wpisany w porządek stworzenia oraz w porządek Odkupienia. Stąd Dzień Pański (Dies Domini) niedziela - dzień szczególnej obecności Boga i Jego błogosławieństwa. Ci, którzy przeszli do nowej nadziei są żyjącymi ,według dnia Pańskiego (iuxta dominicam viventes)" ${ }^{49}$. Niedziela

jest ona Dies Domini w odniesieniu do dzieła stworzenia; Dies Christi jako dzień nowego stworzenia oraz daru Ducha Świętego, którego zmartwychwstały Pan udziela; Dies Ecclesiae jako dzień, w którym wspólnota chrześcijańska zbiera się dla celebracji; Dies hominis jako dzień radości, odpoczynku oraz braterskiej miłości ${ }^{50}$.

Albowiem „z tego dnia rzeczywiście wypływa sens chrześcijańskiej egzystencji oraz nowy sposób przeżywania czasu, więzi, pracy, życia oraz śmierci”"51. W tym

\footnotetext{
$47 \quad$ Ibidem, s. 53-54.

48 Jan Paweł II, List apostolski Dies Domini, n. 14.

49 św. Ignacy z Antiochii, List do Magnezjan, 9, 1.

50 Benedykt XVI, Adhortacja apostolska Sacramentum caritatis, 73.

51 Ibidem.
} 
też Dniu „człowiek wznosi swój głos do Boga, stając się rzecznikiem całego stworzenia" ${ }^{\prime 2}$.

Ten Dies Domini, „dzień Pański jest również dniem wolnym od pracy”53, to

również dzień wolny od codziennego trudu. Ma to ważne znaczenie, ponieważ mówi o relatywizacji pracy, która powinna być nakierowana na cel, jakim jest człowiek: praca jest dla człowieka, a nie człowiek dla pracy. Łatwo można w tym widzieć ochronę daną człowiekowi przed możliwą formą zniewolenia. (...) Praca ma pierwszorzędne znaczenie dla realizacji człowieka i dla rozwoju społeczeństwa. Musi być zatem organizowana i wykonywana z pełnym poszanowaniem ludzkiej godności i w duchu służby dobru wspólnemu. Jest również ważne, aby człowiek nie stał się niewolnikiem pracy, by nie traktował jej w sposób bałwochwalczy sądząc, że to właśnie ona nadaje ostateczny i definitywny sens życiu. W dniu poświęconym Bogu człowiek odnajduje sens swego istnienia, jak również swego pracowitego wysiłku ${ }^{54}$.

\section{Peccatum originale}

Stwórcze dzieło Boże pochodzi z Jego nieskończonej dobroci płynącej z miłości: „Bóg jest miłością” (1 J 4, 8.16), dlatego wszystkie dzieła Jego są dobre: „A Bóg widział, że wszystko, co uczynił, było bardzo dobre” (Rdz 1,31). Skąd więc zło i śmierć? - „przez zawiść diabła” (Mdr 2, 24). Jak mówi Pismo:

A wąż był bardziej przebiegły niż wszystkie zwierzęta lądowe, które Pan Bóg stworzył. On to rzekł do niewiasty: Czy rzeczywiście Bóg powiedział: Nie jedzcie owoców ze wszystkich drzew tego ogrodu? Niewiasta odpowiedziała wężowi: Owoce z drzew tego ogrodu jeść możemy, tylko o owocach z drzewa, które jest w środku ogrodu, Bóg powiedział: Nie wolno wam jeść z niego, a nawet go dotykać, abyście nie pomarli. Wtedy rzekł wąż do niewiasty: Na pewno nie umrzecie! Ale wie Bóg, że gdy spożyjecie owoc $z$ tego drzewa, otworzą się wam oczy i tak jak Bóg będziecie znali dobro i zło. Wtedy niewiasta spostrzegła, że drzewo to ma owoce dobre do jedzenia, że jest ono rozkoszą dla oczu i że owoce tego drzewa nadają się do zdobycia wiedzy. Zerwała zatem z niego owoc, skosztowała i dała swemu mężowi, który był z nią: a on zjadł. A wtedy otworzyły się im obojgu oczy i poznali, że są nadzy; spletli więc gałązki figowe i zrobili sobie przepaski. Gdy zaś mężczyzna i jego żona usłyszeli kroki Pana Boga przechadzającego się po ogrodzie, w porze kiedy był powiew wiatru, skryli się przed Panem Bogiem wśród drzew ogrodu. Pan Bóg zawołał na mężczyznę i zapytał go: Gdzie jesteś? On odpowiedział: Usłyszałem Twój głos w ogrodzie, przestraszyłem się, bo jestem nagi, i ukryłem się. Rzekł Bóg: Któż ci powiedział, że jesteś nagi? Czy może zjadłeś z drzewa, z którego ci zakazałem jeść? Mężczyzna odpowiedział: Niewiasta, którą postawileś przy mnie, dała mi owoc z tego drzewa i zjadłem. Wtedy Pan Bóg rzekł do niewiasty: Dlaczego to uczyniłaś? Niewiasta odpowiedziała: Wąż

52 Jan Paweł II, List apostolski Dies Domini, n. 15.

53 Benedykt XVI, Adhortacja apostolska Sacramentum caritatis, 74

54 Ibidem. 
mnie zwiódł i zjadłam. Wtedy Pan Bóg rzekł do węża: Ponieważ to uczyniłeś, bądź przeklęty wśród wszystkich zwierząt domowych i polnych; na brzuchu będziesz się czołgał i proch będziesz jadł po wszystkie dni twego istnienia. Wprowadzam nieprzyjaźn między ciebie a niewiastę, pomiędzy potomstwo twoje a potomstwo jej: ono zmiażdży ci głowę, a ty zmiażdżysz mu piętę. Do niewiasty powiedział: Obarczę cię niezmiernie wielkim trudem twej brzemienności, w bólu będziesz rodziła dzieci, ku twemu mężowi będziesz kierowała swe pragnienia, on zaś będzie panował nad tobą. Do mężczyzny zaś Bóg rzekł: Ponieważ posłuchałeś swej żony i zjadłeś z drzewa, co do którego dałem ci rozkaz w słowach: Nie będziesz z niego jeść - przeklęta niech będzie ziemia $z$ twego powodu: $w$ trudzie będziesz zdobywał od niej pożywienie dla siebie po wszystkie dni twego życia. Cierń i oset będzie ci ona rodziła, a przecież pokarmem twym są płody roli. W pocie więc oblicza twego będziesz musiał zdobywać pożywienie, póki nie wrócisz do ziemi, z której zostałeś wzięty; bo prochem jesteś i w proch się obrócisz! Mężczyzna dał swej żonie imię Ewa, bo ona stała się matką wszystkich żyjących. Pan Bóg sporządził dla mężczyzny i dla jego żony odzienie ze skór i przyodział ich. Po czym Pan Bóg rzekł: Oto człowiek stał się taki jak My: zna dobro i zło; niechaj teraz nie wyciągnie przypadkiem ręki, aby zerwać owoc także z drzewa życia, zjeść go i żyć na wieki. Dlatego Pan Bóg wydalił go z ogrodu Eden, aby uprawiał tę ziemię, z której został wzięty. Wygnawszy zaś człowieka, Bóg postawił przed ogrodem Eden cherubów i połyskujące ostrze miecza, aby strzec drogi do drzewa życia $(\operatorname{Rdz} 3,1-24)$.

Człowiek daje się zwieść. Przekracza granice, które wyznacza mu stworzoność. To przecież Bóg jest źródłem życia i tylko On jest Panem człowieka, nikt inny.

Zapis z Księgi Rodzaju stanowi źródło pierwszorzędne. Widać tutaj, jak człowiek, „za poduszczeniem Złego już na początku historii nadużył swej wolności, przeciwstawiając się Bogu i pragnąc osiągnąć swój cel poza Nim" ${ }^{55}$. Człowiek dokonuje wyboru wbrew woli Stwórcy, zawierzając wężowi, kusicielowi, kłamcy. Odwraca się od Boga, który jest miłością, a wierzy temu, który „od początku był zabójcą" (J 8, 44). Albowiem

Człowiek, który przedtem (w stanie pierwotnej sprawiedliwości) obcował w przyjaźni i w zaufaniu ze Stwórcą w całej prawdzie swojej duchowo-cielesnej istoty, stworzonej na obraz Boga, obecnie utracił podstawę owej przyjaźni i przymierza. Utracił łaskę uczestnictwa w życiu Boga: dobro należenia do Boga w świętości pierwotnego poddania i synostwa. Grzech natychmiast dał znać o sobie w całym istnieniu i zachowaniu tego pierwszego człowieka: mężczyzny i niewiasty, objawiając się wstydem z powodu popełnionego przewinienia, a w konsekwencji z własnej sytuacji grzeszników, z kolei zaś bojaźnią wobec Boga ${ }^{56}$.

55 Sobór Watykański II, Konstytucja duszpasterska o Kościele Gaudium et spes (dalej: KDK), 13.

56 Jan Paweł II, Wierze w Jezusa Chrystusa Odkupiciela, Libreria Editrice Vaticana 1989, s. 34-35. 
Biblijny przekaz o grzechu pierwszych ludzi ukazuje uprzywilejowany locus objawienia o grzechu pierworodnym ${ }^{57}$. Podkreśla zewnętrzny wpływ na człowieka oraz niewłaściwe używanie wolności, jak wyraża to Psalm

Uznaję bowiem moją nieprawość, a grzech mój jest zawsze przede mną. Tylko przeciw Tobie zgrzeszyłem i uczyniłem, co złe jest przed Tobą, tak że się okazujesz sprawiedliwym w swym wyroku i prawym w swoim osądzie. Oto zrodzony jestem w przewinieniu i w grzechu poczęła mnie matka (Ps 51[50],5-7).

Grzech przechodzi przez serce człowieka (por. Jr 2; Ez 16, 1-34; Oz 2), obciąża całą ludzkość, przychodzi przez pierwszego człowieka (por. Mdr 2).

Tylko Bóg jest dobry (por. Mk 10,18) oraz wszystko, co od Niego pochodzi, jest dobre (por. $\mathrm{Rdz} 1,31$ ) i pozostaje takim, ale w relacji do Niego. W dialogu z pierwszą niewiastą kusiciel odwraca tę relację. Ukazuje ją jako przeciwną dobru, wolności człowieka. Skłania, by człowiek przekroczył granice stworzoności i stał się jak Stwórca, chociaż kusiciel sam doświadcza skutków takiego zuchwalstwa. Mimo to, jawi się ono (przekroczenie stworzoności), by stać się jak Stwórca, realne do osiągnięcia i bardzo pociągające, przedstawione przez kusiciela jako dobro, piękno i wolność, po decyzji staje się tragicznym mirażem.

Tylko Bóg jest Panem człowieka oraz źródłem jego wiedzy i życia. Człowiek przez grzech przekroczył granice, które wyznacza mu Stworzoność, a więc sam Stwórca przez stworzenie. Nie dowierzając Bogu, wbrew Jego przykazaniu, chce rozporządzać wszystkim: wiedzą, życiem, według mowy kusiciela, „tak jak Bóg będziecie znali dobro i zło" ( $\mathrm{Rdz} 3,5)$. Nieposłuszeństwo kusiciela wchodzi w człowieka, pociągając drugiego.

Skutki przestępstwa Adama i Ewy ukazują treść (postać) zła w życiu człowieka i ludzkości. Grzech, który polega na nieposłuszeństwie Bogu, odejściu od Boga, wyobcowuje człowieka. Człowiek staje się obcy względem Boga, zostają zerwane relacje z Bogiem, zażyłość i komunia, pojawia się lęk przed Bogiem. Człowiek staje się obcy sam sobie. Staje się obcy współczłowiekowi, pojawia się degeneracja odniesienia mężczyzna - niewiasta, zerwanie harmonii małżeńskiej w wyjątkowej komunii - ,jedno ciało”; obcy życiu - ból rodzenia, stwórczego owocu jedności w miłości. Człowiek staje się obcy otaczającemu światu - zepsucie odniesienia do rzeczywistości.

Sobór Watykański II stwierdza:

człowiek stworzony przez Boga w stanie sprawiedliwości, za poduszczeniem Złego już na początku historii nadużył swej wolności, przeciwstawiając się Bogu i pragnąc osiągnąć cel swój poza Nim. Poznawszy Boga, nie oddali Mu czci jako Bogu, lecz zaćmione zostało ich bezrozumne serce i służyli raczej stworzeniu niż Stworzycielowi. To, co wiemy dzięki Bożemu Objawieniu, zgodne jest z doświadczeniem. Człowiek 
bowiem, wglądając w swoje serce dostrzega, że jest skłonny także do złego i pogrążony w wielorakim złu, które nie może pochodzić od dobrego Stwórcy. Wzbraniając się często uznać Boga za swój początek, burzy należyty stosunek do swego celu ostatecznego, a także całe swoje uporządkowane nastawienie czy to w stosunku do siebie samego, czy do innych ludzi i wszystkich rzeczy stworzonych ${ }^{58}$.

Grzech panuje powszechnie nad ludźmi, nad ludzkością jako władanie śmierci. Powszechność grzechu nie zamyka się jednak w sobie: „Wiara chrześcijańska uczy, że śmierć cielesna, od której człowiek byłby wolny, gdyby nie był zgrzeszył, zostanie przezwyciężona, gdy wszechmocny i miłosierny Zbawca przywróci człowiekowi zbawienie z jego winy utracone. Bóg bowiem powołał i powołuje człowieka, aby przylgnął do Niego całą swą naturą w wiecznym uczestnictwie nieskazitelnego życia Bożego. To zwycięstwo odniósł Chrystus zmartwychwstały, uwalniając swą śmiercią człowieka od śmierci ${ }^{59}$.

\section{Nowe stworzenie - nowe życie w Chrystusie}

„W Nim zostało wszystko stworzone” (Kol 1, 16). Przez grzech człowiek utracił wspólnotę z Bogiem, do której przez stworzenie został przeznaczony, jednakże pozostał „obrazem Bożym”. To nie grzech ma ostatnie słowo, lecz zbawcza wola Boga: „Wprowadzam nieprzyjaźń między ciebie a niewiastę, pomiędzy potomstwo twoje a potomstwo jej: ono zmiażdży ci głowę, a ty zmiażdżysz mu piętę" ( $\operatorname{Rdz} 3,15)$. Od początku w strukturach naturalnych działa zbawcza wola Boża w Jezusie Chrystusie. Gdyż

On jest obrazem Boga niewidzialnego - Pierworodnym wobec każdego stworzenia, bo w Nim zostało wszystko stworzone: i to, co w niebiosach, i to, co na ziemi, byty widzialne i niewidzialne, czy Trony, czy Panowania, czy Zwierzchności, czy Władze. Wszystko przez Niego i dla Niego zostało stworzone. On jest przed wszystkim i wszystko w Nim ma istnienie. I On jest Głową Ciała - Kościoła. On jest Początkiem, Pierworodnym spośród umarłych, aby sam zyskał pierwszeństwo we wszystkim. Zechciał bowiem (Bóg), aby w Nim zamieszkała cała Pełnia, i aby przez Niego znów pojednać wszystko z sobą: przez Niego - i to, co na ziemi, i to, co w niebiosach, wprowadziwszy pokój przez krew Jego krzyża (Kol 1, 15-20).

Głęboka jedność Stworzenia i Odkupienia ukazuje zbawcze działanie Trójcy Świętej, którego Pośrednikiem jest Słowo Wcielone. Albowiem

Odkupienie - to nowe stworzenie w Chrystusie. Jest ono darem Boga, jest łaską, a równocześnie niesie w sobie wezwanie skierowane do człowieka. Człowiek musi współdziałać w dziele tego duchowego wyzwolenia, jakie sprawuje w nim Bóg przez Chrystusa. „Łaską bowiem jesteście zbawieni przez wiarę. A to pochodzi nie od 
was, lecz jest darem Boga; nie z uczynków, aby się nikt nie chlubił” (Ef 2, 8). Jeśli człowiek nie może przypisywać sobie samemu zbawienia, zbawczego wyzwolenia, które jest darem Boga w Chrystusie, to równocześnie też musi widzieć w tym darze nieustające źródło wezwania do czynów godnych takiego daru. Pełny obraz zbawczego wyzwolenia człowieka zawiera w sobie głęboką świadomość daru Boga w Chrystusowym krzyżu i zmartwychwstaniu odkupieńczym, a równocześnie świadomość odpowiedzialności za ten dar: świadomość zobowiązań natury duchowej i moralnej ${ }^{60}$.

W każdym wydarzeniu historyczno-zbawczym czynny jest Duch Święty. Jezus Chrystus za sprawą Ducha Świętego nie tylko istnieje, ale i działa. „Odkupienie dokonane przez Chrystusa, który nieustannie działa mocą swego Ducha Prawdy (Ducha Ojca i Syna: Ducha Prawdy), posiada swój wymiar wewnętrzno-osobowy, dotyczy każdego człowieka, równocześnie zaś posiada wymiar międzyludzki i społeczny, wspólnotowy i uniwersalny"61.

W Jezusie Chrystusie dokonuje się zjednoczenie odkupionych, communio sanctorum:

On bowiem (Chrystus) jest naszym pokojem. On, który obie części [ludzkości] uczynił jednością, bo zburzył rozdzierający je mur - wrogość. W swym ciele pozbawił On mocy Prawo przykazań, wyrażone w zarządzeniach, aby z dwóch [rodzajów ludzi] stworzyć w sobie jednego nowego człowieka, wprowadzając pokój, i [w ten sposób] jednych, jak i drugich znów pojednać z Bogiem, w jednym Ciele przez krzyż, w sobie zadawszy śmierć wrogości (Ef 2, 14-16).

W Chrystusie, przez Jego Mękę, Śmierć i Zmartwychwstanie, zostało przezwyciężone to, co przez grzech oddziela człowieka od Boga, człowieka od człowieka oraz człowieka samego w sobie:

Oto definitywny wymiar „nowego stworzenia” i „nowości życia” w Chrystusie: wyzwolenie z podziału, „zburzenie muru” dzielącego Izrael od reszty. W Chrystusie wszyscy są „ludem wybranym”, bo w Chrystusie człowiek jest wybrany. Każdy człowiek, bez wyjątku i różnicy, zostaje pojednany z Bogiem i - przez to samo - wezwany do udziału w odwiecznej Bożej Obietnicy Zbawienia i życia. Tak więc cała ludzkość jest stworzona na nowo, jako „człowiek nowy według Boga w sprawiedliwości i prawdziwej świętości" (por. Ef 4, 24). Pojednanie wszystkich z Bogiem przez Chrystusa ma stawać się pojednaniem wszystkich pomiędzy sobą: wspólnotowy i uniwersalny wymiar Odkupienia ${ }^{62}$.

Wszyscy ludzie są wybrani przez Boga w Jezusie Chrystusie. Bo w Jezusie Chrystusie spełniły się wszystkie obietnice i w Nim „nadeszła pełnia czasu” (Ga 4, 4). „Świat, który - jak wierzą chrześcijanie - z miłości Stwórcy powołany

\footnotetext{
60 Jan Paweł II, Wierze w Jezusa Chrystusa Odkupiciela..., s. 465.

61 Ibidem, s. 466.

62 Ibidem.
} 
do bytu i zachowywany, popadł wprawdzie w niewolę grzechu, lecz został wyzwolony przez Chrystusa ukrzyżowanego i zmartwychwstałego, po złamaniu potęgi Złego" ${ }^{63}$.

\section{Wymiar eschatologiczny}

Cała egzystencja ludzka jest z Boga i cała zwraca się ku Bogu, a pełnię swoją znajduje w oglądaniu Boga twarzą w twarz:

Wiemy też, że Bóg z tymi, którzy Go milują, współdziała we wszystkim dla ich dobra, z tymi, którzy są powołani według [Jego] zamiaru. Albowiem tych, których od wieków poznał, tych też przeznaczył na to, by się stali na wzór obrazu Jego Syna, aby On był pierworodnym między wielu braćmi. Tych zaś, których przeznaczył, tych też powołał, a których powołał - tych też usprawiedliwił, a których usprawiedliwił - tych też obdarzył chwałą (Rz 8, 28-30).

Śmierć i Zmartwychwstanie Jezusa Chrystusa to nowe stworzenie, początek nowego świata, w tym świecie. Prawdziwy eschaton otwierający rzeczywistość ostateczną i bezwzględną, „albowiem w tym wydarzeniu obwieszczono już «sąd» nad ludzkością i nad światem. Chrystus jest celem człowieka, centrum kosmosu i historii, i dlatego jest Życiem, Życiem wiecznym, czyli prawdziwym, dla jednostki i narodów" ${ }^{64}$.

Chrystus bowiem, Jego śmierć krzyżowa jest Odkupieniem (por. 1 Kor 6, 20; 1 P 1, 18-19), wyzwoleniem z niewoli grzechu (por. Rz 7; J 8, 34-36), szatana (por. J 8, 44; $1 \mathrm{~J} 38$ ), mocy tego świata (por. Ga 4, 3; Kol 2, 20), śmierci (por. $\mathrm{Rz} 8,2)$.

Krzyż - znak zwycięstwa jest znakiem nadziei. Albowiem Jezus Chrystus ukrzyżowany i zmartwychwstały jest fundamentem naszej nadziei i sprawcą naszego zmartwychwstania, dawcą niezniszczalnego życia.

Tak więc

od grobu Chrystusa historia dokonuje zwrotu i każda chwila przechodzi przez formę niepowtarzalnej śmierci i Zmartwychwstania Pana. Jednak warunkiem umożliwiającym to wypełnienie w Chrystusie, eschaton, jest tajemnica Trójcy Świętej. Kiedy miłość Ojca wywyższa Syna na swoją prawicę, wówczas chwała Zmartwychwstałego umożliwia ludzkości pełną gloria Dei, która od zawsze jest zawarta, choć ukrycie, w przedziwnym pięknie bytu. Duch, którego Jezus ukrzyżowany wydał na krzyżu, a po Zmartwychwstaniu przekazał swoim uczniom (J 2, 22), otwiera drogę umożliwiającą każdemu człowiekowi udział - i to od razu - w życiu Boga samego, w miłości między Ojcem i Synem. Skoro świat stworzony miał swój początek w łonie

63 KKK 421; por. KK 2.

64 A. Scola, Osoba ludzka..., s. 393. 
trynitarnej miłości, to jego przeznaczeniem jest ponowne wkroczenie w tę tryskającą miłość, w której znajduje swoje wypełnienie ${ }^{65}$.

W Zmartwychwstaniu Jezusa okazuje się w sposób ostateczny kim jest Bóg. Ten, który ma władzę nad życiem i śmiercią, bytem i niebytem. Bóg, który jest Życiem i Dawcą życia, Miłością, Stwórczą Miłością oraz Wiernością, któremu należy całkowicie zawierzyć i oprzeć, i wtedy, gdy rozwiewają wszystkie ludzkie możliwości.

Wiara w Zmartwychwstanie Chrystusa daje

pewność, iż życie dane człowiekowi także w ciele śmiertelnym jest przeznaczone do ostatecznego wypełnienia. W tym kontekście można rozumieć własną śmierć jako narodziny (dies natalis) otwierające nas na posiadanie Boga i spełniające wymogi typowe dla stworzeń w najwyższej nadziei na zmartwychwstanie ciał (por. 1 Kor 15, 35nn). Śmierć jednostki, dzięki zwycięstwu Ukrzyżowanego, nie jest już „czystym zniknięciem”, ale prawdziwym narodzeniem w odwiecznym objęciu Ojca (por. Łk 23, 43). Nasza śmierć zawiera w sobie podobieństwo śmierci, tragizm, który może wywoływać opór, bunt, ale pod tym podobieństwem kryje się już prawdziwe życie. Można powiedzieć wraz z Pawłem, że żyjemy „radośni w boleściach” (2 Kor 6, 10) i że staliśmy się zdolni przeżyć naszą egzystencję jako ćwiczenie się naszej wolności. Nasze cierpienie dopełnia w ten sposób to, „czego brakuje cierpieniom Chrystusa" (Kol 1, 24): obiektywnie nie brakuje niczego Odkupieniu, niczego poza naszą wolnością, a w końcu poza całkowitym ofiarowaniem nas samych w śmierci - w Nim. Doświadczenie śmierci tylu naszych braci i sióstr, a zwłaszcza świętych, pozwala nam poznać konkretnie to, co zawiera w sobie zwycięstwo Chrystusa - dla naszej śmierci ${ }^{66}$.

I usłyszałem donośny głos mówiący od tronu: Oto przybytek Boga z ludźmi: i zamieszka wraz z nimi, i będą oni jego ludem, a On będzie Bogiem z nimi. I otrze z ich oczu wszelką łzę, a śmierci już odtąd nie będzie. Ani żałoby, ni krzyku, ni trudu już (odtąd) nie będzie, bo pierwsze rzeczy przeminęly. I rzekł Zasiadający na tronie: Oto czynię wszystko nowe (Ap 21, 3-5).

I Miastu nie trzeba słońca ni księżyca, by mu świeciły, bo chwała Boga je oświetliła, a jego lampą - Baranek (Ap 21, 23).

$* * *$

„Antropologię teologiczną powinno się więc kształtować w ten sposób, by ścisła więź między wiarą a Objawieniem uwidoczniała się jako coś wewnętrznego

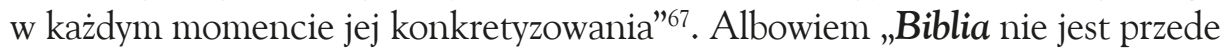

\begin{tabular}{ll}
\hline 65 & Ibidem, s. 393-394. \\
66 & Ibidem, s. 394. \\
67 & Ibidem, s. 44.
\end{tabular}


wszystkim wizją, jaką człowiek ma o Bogu, lecz widzeniem, jakie Bóg ma o człowieku. Biblia nie jest teologią człowieka, lecz antropologią Boga, który zajmuje się człowiekiem i tym, czego on wymaga, bardziej, aniżeli samą naturą Boga"68.

Antropologia teologiczna jest bowiem prawdą o człowieku i jego przeznaczeniu. „Mówi Ten, który o tym świadczy: «Zaiste, przyjdę niebawem». Amen. Przyjdź, Panie Jezu! Łaska Pana Jezusa ze wszystkimi!” (Ap 22, 20-21).

Słowa klucze: Bóg, Stworzyciel, Trójca Święta, stworzenie, mężczyzna i kobieta, grzech, Jezus Chrystus, miłość, przebaczenie, miłosierdzie, Odkupienie, zbawienie, antropologia, eschatologia.

\section{Bibliografia:}

1. Augustyn, De civitate Dei, XI,24.

2. Augustyn, Tract. In Joh. 20.9.

3. Benedykt XVI, Adhortacja apostolska Sacramentum caritatis.

4. Benedykt XVI, Encyklika Deus caritas est.

5. Grzegorz Wielki, Hom 34 in evang 8.

6. Heschel A. J., Uomo non e solo, Milano 1970.

7. Ignacy z Antiochii, List do Magnezjan.

8. Jan Paweł II, Adhortacja Apostolska Familiaris consortio.

9. Jan Paweł II, List apostolski Dies Domini.

10. Jan Paweł II, List apostolski Mulieris dignitatem.

11. Jan Paweł II, Mężczyzna i niewiasta stworzyt ich, Libreria Editrice Vaticana 1986.

12. Jan Paweł II, Wierze w Jezusa Chrystusa Odkupiciela, Libreria Editrice Vaticana 1989.

13. Leon I, Ep. „Quam landebiliter” ad Turib. Ep. Astur (21.07.447), DS 285.

14. Ordo Romanus baptismalis (XI w.), DS 30, BFn IX,4.

15. Scheffczyk L., Schöpfung als Heilseröffnung. Schöpfungslehre, Aachen 1997.

16. Scola A., Osoba ludzka. Antropologia teologiczna, Poznań 2005.

17. Sobór Florencki, Decretum pro Jacobitis (1442 r.), DS 1333.

18. Sobór Laterański IV, De fide catholica (1215 r.), DS 800, BFn IV 33.

19. Sobór Watykański II, Konstytucja duszpasterska o Kościele Gaudium et spes.

20. Tomasz z Akwinu, S. th.

21. Tomasz z Akwinu, Scriptum de Sententiis. Liber primus.

22. Tomasz z Akwinu, Scriptum de Sequentiis. Liber primus.

23. Tomasz z Akwinu, Questiones disputate de Potentia Dei.

68 A. J. Heschel, Uomo non e solo, Milano 1970, s. 135. 